\title{
Testing the Environmental Kuznets Curve Hypothesis in North America's Free Trade Agreement (NAFTA) Countries
}

\author{
Raul Arango Miranda ${ }^{1, *} \mathbb{C}$, Robert Hausler ${ }^{1}$, Rabindranarth Romero Lopez ${ }^{2, *}$, Mathias Glaus ${ }^{1}$ \\ and Jose Ramon Pasillas-Diaz ${ }^{3}$ \\ 1 Station Expérimentale des Procédés Pilotes en Environnement, École de Technologie Supérieure, \\ Université du Québec, 1100 rue Notre-Dame Ouest Local A-1500, Montréal, QC H3C 1K3, Canada; \\ robert.hausler@etsmtl.ca (R.H.); mathias.glaus@etsmtl.ca (M.G.) \\ 2 Unidad de Investigación Especializada en Hidroinformática y Tecnología Ambiental, Facultad de Ingeniería \\ Civil, Universidad Veracruzana, Lomas del Estadio s/n, Zona Universitaria, Xalapa, Veracruz, CP 91000, \\ Mexico \\ 3 Departamento de informática, Universidad Autónoma de Zacatecas, Carretera Zacatecas-Guadalajara Km. 6, \\ Ejido “La Escondida”, Zacatecas, CP 98160, Mexico; jose-ramon.pasillas-diaz.1@ens.etsmtl.ca \\ * Correspondence: raul.arango-miranda.1@ens.etsmtl.ca (R.A.M.); rabromero@uv.mx (R.R.L.)
}

Received: 1 May 2020; Accepted: 8 June 2020; Published: 16 June 2020

check for updates

\begin{abstract}
In force since 1994, the North American Free Trade Agreement (NAFTA) is still the most comprehensive agreement ever developed, conforming to the world's largest trade market. However, the environmental impacts cannot be neglected, particularly greenhouse gas emissions. The environmental Kuznets curve (EKC) hypothesis is revisited, studying Canada, Mexico, and the U.S.A. in relation to carbon dioxide $\left(\mathrm{CO}_{2}\right)$ emissions, gross domestic product (GDP), energy, and exergy consumption. Ordinary least squares, vector autoregression, and Granger causality tests are conducted. Additionally, exergy indicators and the human development index (HDI) are proposed. Results for Mexico and the U.S.A. describe similar and interesting outcomes. In the search of the environmental Kuznets curve (EKC), the EKC hypothesis is confirmed for Mexico and the U.S.A. However, for Canada, the EKC hypothesis does not stand. The Granger causality test displays the existence of a uni-directional causality running from $\mathrm{CO}_{2}$ emissions to economic growth; a similar behavior was observed while testing the for the exergetic control variables. The most intriguing Granger causal results are those from the U.S.A. A bidirectional relation was observed between exergy intensity and $\mathrm{CO}_{2}$ emissions. Moreover, the EKC curve was plotted by both variables. Furthermore, Mexico's outcomes reveal that increasing renewable exergy share will decrease $\mathrm{CO}_{2}$ emissions. On the contrary, increasing HDI will grow $\mathrm{CO}_{2}$ emissions. Policy implications arise for NAFTA countries to minimize $\mathrm{CO}_{2}$ emissions by means of the growing renewable energy share. Exergy tools offer an appealing insight into energetic and environmental strategies.
\end{abstract}

Keywords: climate change; economic growth; energy policy; exergy analysis; environmental Kuznets curve; NAFTA; greenhouse gases

\section{Introduction}

In force since 1994, the North American Free Trade Agreement (NAFTA) is still the most comprehensive agreement ever developed, conforming to the world's largest trade market for goods and services. Most economists agree that NAFTA provided benefits to the North American economy, expanding trade and economic linkages between countries. No doubt, NAFTA reshaped the area not only in economic terms, but also in labor, cultural, and economic fashions, and of 
course also in environmental protection. The agreement also was the first of numerous trade agreements in the Western hemisphere and other parts of the world. Despite the benefits, due to its inherent complexity, the agreement needs to evolve, and since 2017 efforts to improve it have taken place. Those culminated in a new version of the agreement, currently not yet implemented, in a new trilateral United States-Mexico-Canada trade agreement (USMCA). Future implications to the NAFTA or USMCA, are expected to modify specific industrial activities such as the automobile, steel, aluminum, textile, and apparel industries, as well as influence labor and updating financial services, among other topics. In addition, this new agreement brings the opportunity to improve the trade relationship between Mexico and Canada to face the challenges imposed by the U.S.A. during these negotiations [1]. Additionally, after 26 years in force, NAFTA's environmental impacts cannot be neglected, particularly the emission of greenhouse gases. With rich reserves in fossil fuels, like oil, gas, and coal, NAFTA countries' economies during the past 26 years have been running on fossil fuels. As an energy source, the share of fossil fuels surpasses by far renewable resources. This is another example of why fossil fuels are one of the main sources of global warming, which is the relevance to the scientific community [2]. Related to greenhouse gases, climate change is one of the most challenging world issues in this century [3]. Recent rates of greenhouse gases (GHG) have reached their highest level in history [4]. To combat their incessant growth, the decrease of carbon dioxide $\left(\mathrm{CO}_{2}\right)$ emissions plays a key role. Nearly $90 \%$ of the $\mathrm{CO}_{2}$ emissions have a fossil-fuel source. As the primary greenhouse gas, $\mathrm{CO}_{2}$ emissions contribute approximately $60 \%$ of the total greenhouse effect in the world [5]. Globally, quantification of energy related to $\mathrm{CO}_{2}$ emissions, a byproduct of fossil fuel combustion, is a genuine concern for policymakers.

After periods of economic growth without considering environmental damage, in recent years, measures to reduce fossil fuel consumption, combined with renewable sources, have become the main topic of international debates. Some measures are easier to be implemented in developed countries $[6,7]$. However, regarding developing countries, among other issues, they struggle to keep socio-economic growth, while dealing with energy security. These problems are exacerbated by demographic increase. Population growth, urbanization, and subsequent social and economic transformations influence energy consumption. According to The United Nations (UN) Secretariat predictions, the world population is expected to reach 9.8 billion by 2050 [8]. In developing countries, inhabitants living in urban areas will increase by 2025 to near $60 \%$ (compared to $45 \%$ in 1994); this trend will cause developed countries to increase their rates from $80 \%$ to $90 \%$. Energy is a key input to economic growth and due to the use of fossil fuels, it is linked to pollutant emissions. As an example, a fast wave of global economic growth between 2005 and 2013 caused an increase of over 18.3\% in global GHG emissions; reaching over 35 billion tons just in 2013 [9].

The main goal of this research is to analyze the relations among economic growth, energy consumption, and $\mathrm{CO}_{2}$ emissions, including how social and exergetic variables behave. Vector Autoregression (VAR) and the Granger causality test are utilized. Using real data between 1990 and 2016 in NAFTA countries. First, a set of several variables was determined to test the environmental Kuznets curve (EKC) hypothesis; simultaneously, the influence of exergy indicators as control variables was tested. Second, a set of statistical econometric tests is applied. The remainder of this study is organized as follows: Section 3 describes the analyzed countries. Section 4 displays data sets and the methodological steps applied. Section 5 presents empirical results and interpretations. The conclusions section includes some policy implications.

\section{The Environmental Kuznets Curve (EKC), Energy and Exergy Analysis}

\subsection{EKC Brief Review}

To study the $\mathrm{CO}_{2}$ emissions drivers and to promote green economic development, several studies have been conducted on economic growth, energy consumption, and $\mathrm{CO}_{2}$ emissions relations. The Environmental Kuznets Curve (EKC) is defined by Stern et al. as a hypothesized relationship 
between various indicators of environmental degradation and income per capita [10]. The concept of a causal relationship between energy consumption and economic growth was first introduced by Kraft and Kraft [11]. According to the research of Simon Kuznets, the degree of income inequality decreases with the expansion of the economy, and the relationship between the two shows the characteristics of an inverted U-shaped curve [12]. Grossman and Krueger were pioneers in the search of relations between economic growth and the environment. The model is best described by an inverted U-shaped relationship, the Kuznets curve hypothesis [13].

In this paper, we give an overview of the most relevant existing work in this area of research. We highlighted the reviews of Stern [14] Kaika and Zervas [15,16], and others $[17,18]$ since researchers started to test the validity of the EKC hypothesis. Some studies have been targeting single or multiple countries or even regional scales. [19-21]. Furthermore, even different strands centered the search on the EKC theory, or the causal correlations among variables or combining different socio-economic and environmental variables [22]. Other areas of research have been studying different environmental factors $\left(\mathrm{CO}_{2}, \mathrm{SO}_{2}\right.$, particulate matter, wastewater, hazardous wastes, etc.). Some have even applied different time frames. A wide variety of findings have been described [23]. Concerning the NAFTA countries, Kalayci studied the impact of economic globalization [24]. There is evidence that the results are influenced by the chosen econometric models [25].

\subsection{Exergy, Energy, Environment and the Industrial Sector}

In 2007, Sciubba and Wall [26] best described the evolution of exergy. Starting from the ground-breaking notions by Reistad [27], to links to the environment by Dincer \& Rosen [28]. In 2012 they offered a definition of exergy of a system as: "the maximum shaft work that can be done by the composite of the system and a specified reference environment."Regarding the study of the industrial sector by means of exergy, the literature refers to two main categories: industrial subsectors and industrial devices [29]; also the role of exergy regarding the environment and industrial activities has been studying $[30,31]$. Gong and Wall claim exergy concept should be applied to improve energy and material conversion processes [32]. Decision-takers could apply exergy to increase considerably energy efficiency, enhancing energy policy [33,34]. It may be reported to the best of authors' knowledge, there is very limited literature review about exergy analysis and the $\mathrm{CO}_{2}$ emissions containing the EKC theory by means of Granger causality test, especially involving industrial activities. Consequently, this study is projected to contribute to the body of knowledge.

\section{Materials and Methods}

\subsection{Data Sources and Countries' Socioeconomic and Environmental Profile of the North America's Free Trade Agreement (NAFTA) Countries}

Real data of gross domestic product (GDP, US dollars, 2005) and energy consumption (million tons oil equivalent or MTOE) are analyzed by each one of the NAFTA countries; this takes place for the period of time between 1990 to 2016. Individual data by country were retrieved from IEA's energy balances and the report " $\mathrm{CO}_{2}$ Emissions from Fuel Combustion, IEA 2017" [35,36].

A brief description of the NAFTA countries profile includes de following: in 2016 the population reaches around 490 million people; the trade economy achieves a total GDP of 24.8 trillion with a yearly per capita GDP of US $\$ 50,700$. The countries own near $14 \%$ of the world's landmass, an area of 21,578,200 $\mathrm{km}^{2}$ [1]. Around the world, NAFTA is one of a kind as a trade market area, its relevance is possible only compared with the Eurozone. In comparison, the European Union (EU) a political-economical-social conglomerate of 27 countries, is the second-largest trade zone, with a population estimated by 2020 over 447 million inhabitants, a GDP of 14 trillion and a yearly per capita GDP near US $\$ 36,000$ [37]; covering a geographical zone over 4,233,262 $\mathrm{km}^{2}$. In addition, agreements or accords to establish both the NAFTA and the EU were established around the same timeline, 1992 to 1994; however, NAFTA was the first agreement on its kind, and became one of the most influential 
worldwide. NAFTA has been running since January 1994. During this time, trade between the three NAFTA parties has increased from US \$290 billion in 1993 to over US \$1.1 trillion in 2017 [1].

In economic terms, some similarities are shared among NAFTA countries: economic growth, geographical position, population, and the production of manufacturing goods to exports. They belong to the Organization for Development and Economic Cooperation (OECD); they are members of the International Energy Agency (IEA) as well. Regarding NAFTA countries' environmental profile, they were listed as the world's major top 20 GHG emitters [38]. The Climate Change Performance Index report (CCPI) addresses the climate protection performance of 58 countries. Collectively, the 58 countries are emitting near $90 \%$ of global $\mathrm{CO}_{2}$ emissions. As a group, NAFTA countries produce around $20 \%$ of global $\mathrm{CO}_{2}$ emissions [39].

\subsection{Methods}

Two methodological phases are proposed. In the first one, an energy and exergy analysis was developed to construct a dataset of a selected panel of developed and developing countries previously reported by Arango and colleagues [30]; then a subset of data was extracted and extended accordingly to properly analyze NAFTA countries, and utilize some of them as control variables. The second methodological phase is an econometric analysis, formed by three tests: ordinary least squares (OLS), vector analytic regression (VAR), defined as a stochastic model used to capture the linear interdependencies among multiple time series [40,41]; and the Granger causality test, defined as a statistical hypothesis test for determining whether a time series is useful in forecasting another [23,42]. All tests will be explained thoroughly later, in Section 4.3.

Table 1 presents the descriptive statistics of the dependent and the explanatory variables for the total sample of 3 countries over a period of 26 years. 175 observations per country were analyzed. In order to minimize the issue of heteroscedasticity and to improve the comparability with previous studies, all variables are expressed in natural logarithms. All the underlying sources consist of annual time series data. Any data points were interpolated or extrapolated.

Table 1. Variable definitions and descriptive statistics (average values in NAFTA countries [35,43])

\begin{tabular}{lccccccc}
\hline \multicolumn{1}{c}{ Variable } & Units & Average & Max & Min & Median & Stdr Dev & Rate of Growth \\
\hline $\ln \mathbf{C O}_{2}$ & Mton & 7.6 & 8.6 & 5.5 & 6.2 & 5.0 & 1.41 \\
$\ln$ Enc & PJ & 10.5 & 11.5 & 8.6 & 9.3 & 7.8 & 1.37 \\
$\ln$ GDPpc & USD, 2005 & 10.4 & 10.8 & 8.9 & 10.7 & 7.8 & 1.41 \\
\hline $\ln$ Exint & $\mathrm{TPES} / \mathrm{GDP}$ & 4.6 & 4.8 & 4.3 & 4.6 & 1.3 & 1.40 \\
$\ln$ ExRS & $\%$ & 2.4 & 2.9 & 1.5 & 2.3 & 0.5 & 1.41 \\
$\ln$ TROpn & $\%$ & 3.9 & 4.4 & 3.0 & 3.9 & 1.3 & 1.94 \\
$\ln$ HDI & $\%$ & 0.2 & 0.1 & 0.4 & 0.1 & 4.7 & 1.11 \\
\hline
\end{tabular}

Among the explanatory variables, carbon dioxide emissions, energy consumption, GDP per capita, and trade openness were taken from the IEA website data and statistics. Additionally, the control variables exergy intensity and exergetic renewable share came from the IEA database; however, they were computed as expressed previously in Section 2.2. The Human Development Index comes from UNDP website statistics [43]. The sustained economic trade growth during the studied years was particularly noticeable by Mexico, describing the highest rate of growth with 1.94 .

\subsection{Econometric Analysis}

A basic form of the EKC model, a linear equation approach, is utilized. De Bruyn, Dinda Grossman and Krueger, and Panayotou, among others researchers, have been applying the generalized functional form of the EKC $[19,44-46]$ :

$$
E D=f\left(E G_{i t}, E n C_{i t}, E x C_{i t}, T r O p n_{i t}, H D I, \mu_{i t}\right)
$$


where: $E D=$ Environmental degradation $=\mathrm{CO}_{2} \mathrm{ff} ; E n C=$ Energy consumption of fossil fuels; $G D P p c=$ Economic Growth per capita; $E x R S=$ Exergetic renewable share: Exint = Exergy intensity; TrOpn $=$ Trade openness; $H D I=$ Human development index; $\mu=$ error term. The analysis starts considering a parametric model that is quite standard in the EKC literature and takes the following lineal model form:

$$
E_{t}=\beta_{0}+\beta_{1} * G D P_{i t}+\beta_{2} * G D P_{2 i t}^{2}+\beta_{3} * G D P_{2 i t}^{3} \mu+\sum_{j=1_{i t}}^{k} \gamma_{j} X_{J, I T}+\mu_{i t}
$$

where: $E_{t}$ is per-capita $\mathrm{CO}_{2}$ emissions; $Y_{t}$ is per-capita $\operatorname{lnGDP}$, and $X_{t}$ is a vector of variables that may affect $E_{t}$. In addition, the deterministic time trend (and sometimes its square) is included as a proxy of technological progress. A modified version of Equation (2) is applied to test the influence of an exergetic variable [47]:

$$
C O_{2} f f=\beta_{1} * G D P p c+\beta_{2} * G D P p c_{i t}^{2}+\beta_{3} * G D P p c_{i t}^{3}+\delta_{1} * E n c f f_{i t}+\delta_{2} * E x R S_{i t}
$$

\subsubsection{Ordinary Least Squares Test}

Equation (3) can be solved by ordinary least squares (OLS) method. However, when considering a model with a data panel that combines information over time and cross-section (countries), there is heterogeneity in cross-section observations that cannot be measured or ignored by individual effects [48]. OLS estimators can be inconsistent and biased. The way to include the un-observable effects is defining an error component model, encompassing the sum of two components: a random term and a second component that represents un-observed heterogeneity. For practical reasons, in this study the following conditions were established: The datasets are not stationary, are of the same order of integration, and Granger causalities are confirmed in at least one sense.

\subsubsection{Vector Autoregression (VAR) Test}

An empirical approach applying a panel data vector autoregression methodology is proposed. Variables are considered as endogenous. The panel data approach allows unobserved individual heterogeneity. Subsequently, a similar strategy from previous research was applied [49,50]. The impulse-response functions best describe the reaction of one variable to the improvements in another variable, while holding all other shocks equal to zero [23].

\subsubsection{Granger Causality Test}

Even a long-run relationship was observed among variables, however, is not enough to observe which variable causes the other. Then, the Granger causality test is applied to determine causal relationships. Combining the Granger causal test, also an augmented vector autoregression (VAR) framework will be estimated [51]. The appropriate maximum lag length is determined for the variables in the VAR by using standard methods $[23,52]$.

\section{Emprirical Results and Discussions}

\subsection{Ordinary Least Squares Test}

Carbon dioxide $\left(\mathrm{CO}_{2}\right)$ emissions, exergetic intensity, exergetic renewable share, energy consumption from fossil fuels, GDP per capita, trade openness, and the HDI index are studied. Most of the variables reveal growing trends in the long run. On one end, growing trends of $\mathrm{CO}_{2}$ emissions, energy consumption, economic growth, trade openness, and the Human Development Index are observed. On the other end, decreasing trends of exergy intensity and exergetic renewable share are displayed. Since the focus was to observe $\mathrm{CO}_{2}$ emissions behavior, it describes an increasing pattern, however with some small decreasing steps. Compared to their counterparts, Mexico's $\mathrm{CO}_{2}$ emissions curve growth was steadier. The most interesting curve is depicted by $\mathrm{CO}_{2}$ emissions; a growing trend 
but mostly steady in the long run, rather erratic for the U.S.A. Punctual decrease trends by the three countries were also observed.

This study tests the existence of the four EKC hypothesis for NAFTA countries. The method is similar to those found in previous studies, exploring relations between energy consumption and economic growth. Several authors in the past and recently, have tested the four EKC hypotheses to explore energy consumption and economic growth relations. Additionally, an extended method based on the behavior of the beta $(\beta)$ factors and their influence on the EKC has been applied $[18,19]$. Below, Table 2 shows the results relevant to the EKC hypothesis for NAFTA countries.

Table 2. Environmental Kuznets Curve (EKC) parameters for NAFTA countries.

\begin{tabular}{cccccccc}
\hline & Intercept & Enc & GDPpc & ExRS & Exint & TROpn & HDI \\
\cline { 2 - 7 } Coefficient & & $\mathbf{C O}_{\mathbf{2}}$ & $\boldsymbol{\beta 1}$ & $\boldsymbol{\beta} \mathbf{2}$ & $\boldsymbol{\beta 3}$ & $\boldsymbol{\beta} 4$ & $\boldsymbol{\beta} 5$ \\
\hline Canada & $(-)) 205.0$ & 0.0083 & 0.0066 & 0.8955 & 0.3149 & 0.9521 & 281 \\
Mexico & $(-) 853.7$ & -0.0042 & 0.0319 & $(-) 6.2000$ & 2.0770 & 0.3340 & 1136 \\
U.S.A. & 5644.0 & 0.0814 & $(-) 0.0252$ & $(-) 25.2700$ & -4.7710 & 3.1670 & -6820 \\
\hline
\end{tabular}

According to Özokcu et al. [18], the evidence of an EKC requires a $\beta 1$ positive coefficient, a negative $\beta 2$ coefficient and a $\beta 3$ positive coefficient to obtain a quadratic relation to form an inverted $U$ shape; in this test. Below, Table 2 shows the results relevant to the EKC hypothesis for NAFTA countries.

Results for Canada were consistent with the empirical findings of Ghali and El-Sakka [53]. He et al. [54], reported little evidence of the EKC. Olale et al. [55] confirmed the EKC hypothesis for Canada, however only at the provincial level and not at the country level.

Regarding Mexico's previous studies, Gomez et al. [56] described causal links between energy consumption to economic growth; also the growth hypothesis was observed, proving that energy is an important input factor for economic activity and that energy conservation policies impact the economic growth in Mexico. It is noticeable that exergy intensity is related to energy intensity, plotted in Figure 1a with a decreasing trend during the 26 years of study.

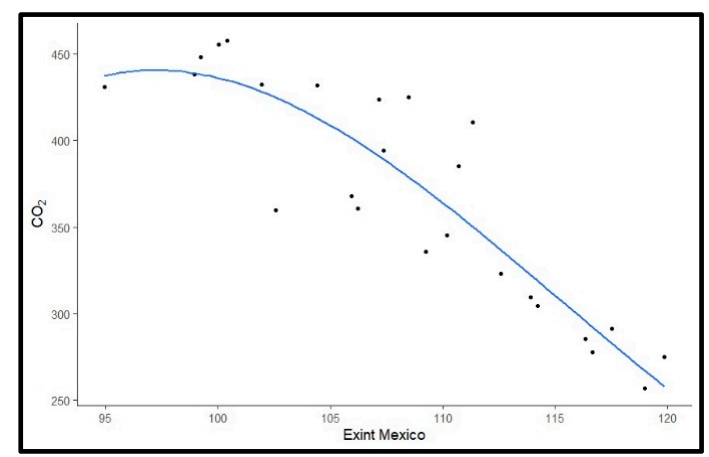

(a)

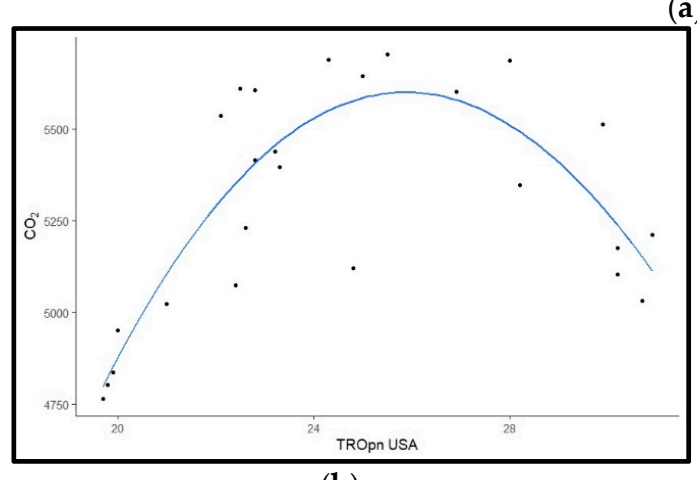

(b)

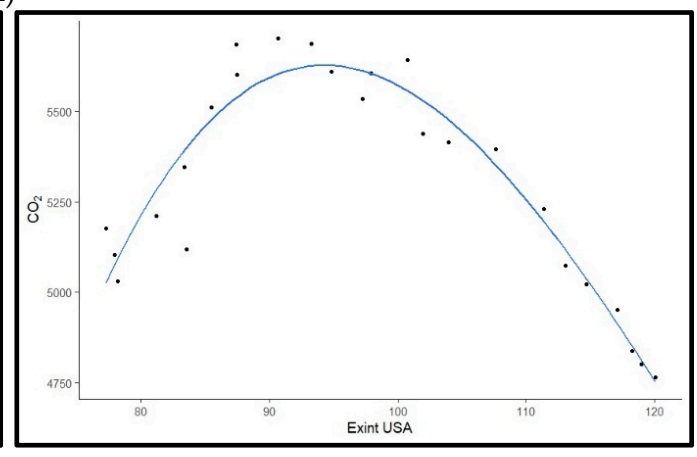

(c)

Figure 1. The environmental Kuznets curve: relationships detected by Mexico and the U.S.A. (a) Exint Mexico; (b) TROpn USA; (c) Exint USA. 
Below, Figure 1 describes results in the search of the EKC for Mexico and the U.S.A. It plots the ratio between the degradation variable, $\mathrm{CO}_{2}$ emissions, and three of the control variables proposed in this research. Figure 1a plots $\mathrm{CO}_{2}$ emissions vs. exergy intensity by Mexico, describing a slight inverted $\mathrm{U}$ curve, with a decreasing trend, supporting the EKC hypothesis.

Figure $1 \mathrm{~b}, \mathrm{c}$ shows U.S.A results; it is plotted, respectively: $\mathrm{CO}_{2}$ emissions-trade openness and $\mathrm{CO}_{2}$ emissions-exergy intensity. Both plots describe the inverted U curve, confirming the EKC hypothesis in terms of trade openness and exergy intensity as control variables. Additionally, focusing on a single country base, the results were consistent with the empirical findings by Baek et al. [57] which showed the EKC initially in the short run. In addition, these results were consistent with the empirical findings of Dogan \& Turkekul [58]. The EKC hypothesis was not confirmed between economic growth and $\mathrm{CO}_{2}$ emissions. It is interesting to observe that causalities of these research and the work of Dogan were found, and this topic will be discussed in Section 4.3.

\subsection{Vector Autoregression (VAR) Test}

This test combines the traditional VAR approach, treating all the variables in the system as endogenous with the panel data approach, allowing for unobserved individual heterogeneity. Here, similar methodological steps suggested by other authors were applied [49].

As noted previously in Section 3.3.2., long-run co-integration and elasticities of the variables were observed, the coefficients of energy consumption and carbon dioxide emissions show statistically significant relationships with economic growth [41]. HDI brings interesting results as a control variable. It was observed that a $1 \%$ increase of the social variable, human development index (HDI), may lead to a huge increase in $\mathrm{CO}_{2}$ emissions (1136\%). HDI could help to explain the influence of the social and economic dimensions of the analyzed countries, and their effects on $\mathrm{CO}_{2}$ emissions. Canada results reveal that a $1 \%$ increase in human development index (HDI) may lead to a considerable increase in $\mathrm{CO}_{2}$ emissions (281\%). Then an increase in the economy could affect the environment.

Mexico's test shows interesting results, especially in the social variable. During the studied years, the HDI index increased $11 \%$, the biggest, compared to the rates of Canada and the U.S.A. However, despite this growth, Mexico's HDI averages by 2015 remain lower than those of Canada and the U.S.A. (16 points below). In comparison, not as drastic as in Mexico's case, in respect of the HDI variable, for the U.S.A., a $1 \%$ may lead to a huge decrease in $\mathrm{CO}_{2}$ emissions $(6820 \%)$. This result displays the differences of the Human Development Index, putting in perspective two main drivers, GDP and population among the three countries.

Regarding the test exergetic renewable share (ExRS) as a control variable, Canada's results are not observed. ExRS to Mexico's shows that a $1 \%$ increase may lead to a $6.2 \%$ decrease in $\mathrm{CO}_{2}$ emissions. Confirming the need to increase Mexico's renewable energy sources. This is a big goal from an oil exporter to boost its future economy with fewer fossil fuels, which is a global trend. Additionally, the U.S.A.'s ExRS results are most interesting results, a $1 \%$ increase may lead to decrease around $25 \%$ of $\mathrm{CO}_{2}$ emissions, highlighting the relevance and need to increase Mexico's renewable share. Paired with renewable sources of fuels, the use of oil reserves in a responsible and more efficient way are priorities to guarantee global energy security [59].

\subsection{Granger Causality Test}

The Granger causality test was applied to determine causal relationships. Co-integration among the variables was observed. It was expected that a one-directional or bi-directional causality would exist between the data time-series in each one of the three countries within an augmented VAR test framework. The proposed exergetic variables, trade openness, and HDI index are tested as control variables. At first sight, the Granger causal relationship test reveals that energy consumption, economic growth, and trade openness are the driving forces of $\mathrm{CO}_{2}$ emissions among NAFTA countries. For Mexico and the U.S.A, the EKC hypothesis is confirmed. However, for Canada, the EKC hypothesis 
does not stand. Yet, the inverted U curve by economic growth was confirmed by Mexico and the U.S.A. Below, Table 3 summarizes all the information relevant to Granger causal test.

Table 3. Granger causality tests.

\begin{tabular}{|c|c|c|c|c|c|c|c|c|}
\hline \multicolumn{9}{|c|}{ Variables } \\
\hline Mexico & $\mathrm{CO}_{2}$ & Enc & GDPpc & ExRS & Exint & TROpn & HDI & $\begin{array}{l}\text { Direction of } \\
\text { Causality }\end{array}$ \\
\hline $\mathrm{CO}_{2}$ & - & 0.0693 & 0.0414 & 0.0992 & 0.2012 & 0.2939 & 0.4259 & \\
\hline Enc & 0.7961 & & & & & & & $\mathrm{Enc} \rightarrow \mathrm{CO}_{2}$ \\
\hline$G D P p c$ & 0.3997 & & & & & & & $\mathrm{GDPpc} \rightarrow \mathrm{CO}_{2}$ \\
\hline ExRS & 0.8922 & & & & & & & ExRS $\rightarrow \mathrm{CO}_{2}$ \\
\hline Canada & $\mathrm{CO}_{2}$ & Enc & GDPpc & ExRS & Exint & TROpn & HDI & \\
\hline $\mathrm{CO}_{2}$ & - & 0.4437 & 0.1098 & 0.8569 & 0.2023 & 0.0584 & 0.1855 & \\
\hline TROpn & 0.5053 & & & & & & & TROpn $\rightarrow \mathrm{CO}_{2}$ \\
\hline U.S.A. & $\mathrm{CO}_{2}$ & Enc & GDPpc & ExRS & Exint & TROpn & HDI & \\
\hline $\mathrm{CO}_{2}$ & - & 0.7356 & 0.6547 & 0.0043 & 0.0324 & 0.2307 & 0.7308 & \\
\hline Enc & 0.0750 & & & & & & & Enc $\rightarrow \mathrm{CO}_{2}$ \\
\hline$G D P p c$ & 0.0019 & & & & & & & $\mathrm{GDPpc} \rightarrow \mathrm{CO}_{2}$ \\
\hline ExRS & 0.1825 & & & & & & & ExRS $\rightarrow \mathrm{CO}_{2}$ \\
\hline Exint & 0.0070 & & & & & & & Exint $\leftrightarrow \mathrm{CO}_{2}$ \\
\hline TROpn & 0.0132 & & & & & & & TROpn $\rightarrow \mathrm{CO}_{2}$ \\
\hline
\end{tabular}

Canada results show only one causal relationship, a unidirectional Granger causality running from trade openness to $\mathrm{CO}_{2}$ emissions.

Mexico's Granger causal test results describe the existence of a one-directional relationship running from energy consumption, economic growth, and the exergetic renewable share to $\mathrm{CO}_{2}$ emissions. It means economic growth during the last 26 years, coupled with energy consumption is traduce in the increase of $\mathrm{CO}_{2}$ emissions. These results are expected by a country that has been increasing its trade and export activities by two to four times since NAFTA is in force.

The most intriguing Granger causal results are described to the U.S.A.; a bi-causal direction was detected between exergy intensity and $\mathrm{CO}_{2}$ emissions. In addition, observed one-directional Granger causalities running from several variables (energy consumption, economic growth, exergetic renewable share, and trade openness) to $\mathrm{CO}_{2}$ emissions were observed.

Compared to the present research, in terms of the method here applied, the study by Soytas et al. [60] shows some similar findings; i.e., energy consumption Granger causes $\mathrm{CO}_{2}$. Soytas concludes income growth by itself may not become a solution to environmental problems. Dogan and Turkekul [58] results from the Granger causality test showed some similarity to our results: there is causality between $\mathrm{CO}_{2}$ and GDP and $\mathrm{CO}_{2}$ and energy consumption; however no causality is determined between $\mathrm{CO}_{2}$ and trade openness. Applying panel data analysis, recently Kalayci [24] studied NAFTA countries, confirming that economic globalization and trade openness leads to boosted $\mathrm{CO}_{2}$ emissions. Similar to this study, the positive correlation between energy consumption and $\mathrm{CO}_{2}$ emissions suggest growing trade activities and energy consumption are drivers of $\mathrm{CO}_{2}$ emissions in NAFTA countries.

The challenge to diminish climate change effects requires global actions. Countries have been committing to establish strong targets to reduce the total emissions of $\mathrm{CO}_{2}$ by 2050, among other pollutants. According to reports from the Panel on Climate Change (IPCC), tougher actions are required from developed and developing economies. The Conference of the Parties (COP) 21, celebrated in Paris in 2015, recognizes that none of the major powers can be forced into drastic emissions cuts. However, it embeds country pledges in an international system of climate accountability, offering the chance of more durable international cooperation [61]. Hence, the scientific community is focused to promote mechanisms to accelerate the evolution of environmental and energetic policies and regulations. 
Increasing energy efficiency and decarbonization to reduce GHG emissions, will help to minimize the climate change impacts.

Manufacturing of goods and consumer care have been key economic activities in NAFTA countries. The economy is based on three main societal sectors: industrial, transformation, and transport. These activities are consuming near $90 \%$ of primary energy supply, unfortunately mostly based on fossil fuels [62]. Certainly, changes are needed in energy efficiency and shifts in the fuel mix. Notably from carbon-intensive coal to low-carbon gas or from fossil fuels to renewable energy sources. These changes could help to curb global air emissions

Regarding the NAFTA countries, a final remark arises. Despite unfinished business to lift the agreement, in near future the logic points out that the North American trade market will surpass a population of 490 million. No doubt, during recent years of negotiations, the environmental and energetic chapters are key issues for a successful agreement. Despite the U.S.A. refusal to sign the Kyoto protocol to combat climate change, the new version of NAFTA (USMCA) has an opportunity to contribute, since Canada and Mexico have already committed to minimize their emissions. Since NAFTA negotiations are almost finished, the environmental chapter relevance increases. The moment for the task forces to start the process to establish goals and methods is on the clock. Consequently, $\mathrm{CO}_{2}$ mitigations and the decarbonization process plays a pivotal role in carbon mitigation plans. The role of decisionmakers is relevant, and results of scientific research are there to support their job.

Mexico's and Canada's geographic positions are privileged in terms of market, since they share borders with the U.S.A., one of the major energy consumers on the global scale. In the search of improvement to reduce prices, proximity is a must. Nearness allows to minimize transport, costs, and times while simultaneously reducing air emissions. Eventually, future manufacturing activities will change. Hence, it is imperative for NAFTA countries to satisfy such demands with greener and secure energy scenarios. Lastly, exergy offers a better and wider approach to decrease energy consumption. Exergy analysis tools can be utilized to enhance energy efficiencies.

\section{Conclusions}

The aim of this research was to analyze relations among economic growth, energy consumption, and $\mathrm{CO}_{2}$ emissions, including how social and exergetic variables behave. Additionally, a set of econometric tests was settled on a place to test the existence of the environmental Kuznets Curve (EKC). Vector autoregression (VAR) and Granger causality tests were applied. The empirical study was based on data sets of NAFTA countries, for the period between the years 1990 to 2016. In the search of the environmental Kuznets curve (EKC) the EKC hypothesis is confirmed for Mexico and the U.S.A. However, for Canada, the EKC hypothesis does not stand.

Mexico's Granger causal results reveal the existence of a one-directional causality running from $\mathrm{CO}_{2}$ emissions to economic growth; a similar behavior was observed for the exergetic renewable share and exergetic renewable share variables. The most intriguing Granger causal results are those from the U.S.A.; a bidirectional relation was observed between exergy intensity and $\mathrm{CO}_{2}$ emissions. Moreover, the EKC curve was plotted by both variables, confirming the relevance on how strong they are related, while growing, reaching a maximum then decreasing. Exergy intensity is a driving force to $\mathrm{CO}_{2}$ emissions. In addition, the existence of one-directional causalities running from several variables (energy consumption, economic growth, exergetic renewable share, and trade openness) to $\mathrm{CO}_{2}$ emissions were observed. Contrasting, in the study of Canada, results show just the existence of a one-directional causality running from $\mathrm{CO}_{2}$ emissions to trade openness.

It is concluded that energy is a limiting factor for economic growth and, therefore, the impact on energy supply will have a negative impact on economic growth. Regardless, results do not hold completely the EKC hypothesis among the trilateral partners of NAFTA; however, the growth hypothesis of the EKC was confirmed by Mexico and the U.S.A. A drop in energy consumption 
will negatively affect economic growth; particularly by Mexico, and negative effects could harm a developing economy.

The cointegration and Granger causal results by the exergetic renewable share remarks the relevance to increase the share of renewable sources, which no doubt is a path to combat global warming and reduce $\mathrm{CO}_{2}$ emissions, enabling the reduction of energy dependency while enhancing energy security. Furthermore, Mexico's outcomes reveal that while increasing renewable exergy share, it will decrease $\mathrm{CO}_{2}$ emissions. On the other hand, increasing $\mathrm{HDI}$ will grow $\mathrm{CO}_{2}$ emissions. It was proved that exergetic variables open the door for future research as control variables. Exergy can be used to assesses energy and environmental policies. It is also a tool to minimize environmental harm, with the possibility to link exergy efficiencies and the use of renewables.

Regarding future policy implications by NAFTA countries, results could help to increase cooperation to address transnational threats. Particularly since current negotiations to reshape the agreement are almost finished, the relevance of the environmental chapter is increasing. Consequently, $\mathrm{CO}_{2}$ mitigations and the decarbonization process strategies like those proposed here, could play a pivotal role in carbon mitigation plans. The role of decisionmakers is crucial, and results of scientific research are there to support their job.

Future research could include tests at country or provincial level, and even sectorial scales to test the relations of environmental and exergetic indicators. Of course, stronger econometric models could also be considered.

Author Contributions: Conceptualization and methodology design: R.A.M., R.H., and R.R.L. Formal analysis: R.A.M. and J.R.P.-D. Data curation and validation: R.A.M., R.R.L., and J.R.P.-D. Writing-Original Draft Preparation: R.A.M., R.H., and R.R.L. Writing-Review \& Editing: R.H., R.R.L., and M.G. Supervision: R.H., R.R.L., and M.G. All authors have read and agreed to the published version of the manuscript.

Funding: This research was funded by the "Consejo Nacional de Ciencia y Tecnología (CONACYT)" and the "Consejo Veracruzano de Investigación Científica y Desarrollo Tecnológico (COVEICYDET") through scholarship (No. 218934) to Raul Arango Miranda.

Conflicts of Interest: The authors declare no conflict of interest.

\section{Abbreviations}

The following abbreviations are used in this manuscript:

$\begin{array}{ll}\text { NAFTA } & \text { North American Free Trade Agreement } \\ \text { EKC } & \text { Environmental Kuznets Curve } \\ \text { GHG } & \text { Green House Gases } \\ \text { VAR } & \text { Vector Autoregression } \\ \text { IEA } & \text { International Energy Agency } \\ \text { UN } & \text { United Nations } \\ \text { IPCC } & \text { Intergovernmental Panel on Climate Change } \\ \mathrm{CCPI} & \text { Climate Change Performance Index report } \\ \mathrm{OECD} & \text { Organization for Development and Economic Cooperation } \\ \mathrm{MTOE} & \text { Million Tons Oil Equivalent } \\ \mathrm{Granger} & \text { Granger causality } \\ \mathrm{CO}{ }_{2} & \text { Carbon dioxide emissions } \\ \mathrm{CO}{ }_{2} f f & \text { Carbon dioxide emissions (of fossil fuels) } \\ E t & \text { Carbon dioxide emissions, per capita } \\ \operatorname{lnCO} \mathrm{O}_{2} & \text { Logarithmic Carbon dioxide emissions } \\ G D P & \text { Gross domestic product, per capita; USD 2005 } \\ \ln G D P & \text { Logarithmic Gross domestic product, per capita; USD 2005 } \\ Y t & \text { Logarithmic Gross domestic product, per capita; USD 2005 } \\ \beta & \text { GDP per capita term coefficients (cubic, quadratic, and primary) } \\ E D & \text { Environmental degradation } \\ E n c & \text { Energy consumption (of fossil fuels) } \\ \operatorname{lnEnc} & \text { Logarithmic energy consumption }\end{array}$




$\begin{array}{ll}\text { En int } & \text { Energy Intensity } \\ \ln \text { En int } & \text { Logarithmic energy Intensity } \\ \text { Exint } & \text { Exergy Intensity } \\ \ln \text { Exint } & \text { Logarithmic exergy Intensity } \\ \text { ExRS } & \text { Exergetic renewable share } \\ \operatorname{lnExRS} & \text { Logarithmic exergetic renewable share } \\ \text { HDI } & \text { Human development index } \\ \operatorname{lnHDI} & \text { Logarithmic human development index } \\ \text { TROpn } & \text { Trade openness } \\ \operatorname{lnTROpn} & \text { Logarithmic trade openness }\end{array}$

\section{References}

1. Burfisher, M.E.; Lambert, F.; Matheson, M.T.D. Nafta to Usmca: What is Gained? IMF Working Paper WP/19/73; International Monetary Fund: Washington, DC, USA, 2019.

2. Focacci, A. Empirical analysis of the environmental and energy policies in some developing countries using widely employed macroeconomic indicators: The cases of brazil, china and india. Energy Policy 2005, 33, 543-554. [CrossRef]

3. Lin, B.; Moubarak, M.; Ouyang, X. Carbon dioxide emissions and growth of the manufacturing sector: Evidence for china. Energy 2014, 76, 830-837. [CrossRef]

4. Meinshausen, M.; Smith, S.J.; Calvin, K.; Daniel, J.S.; Kainuma, M.L.T.; Lamarque, J.-F.; Matsumoto, K.; Montzka, S.A.; Raper, S.C.B.; Riahi, K.; et al. The rcp greenhouse gas concentrations and their extensions from 1765 to 2300. Clim. Chang. 2011, 109, 213. [CrossRef]

5. Ozturk, I.; Acaravci, A. $\mathrm{CO}_{2}$ emissions, energy consumption and economic growth in turkey. Renew. Sustain. Energy Rev. 2010, 14, 3220-3225. [CrossRef]

6. Olivier, J.G.J.; Peters, J.A.H.W.; Janssens-Maenhout, G.; Muntean, M. Trends in Global $\mathrm{CO}_{2}$ Emissions. 2013 Report; The Netherlands Environmental Assessment Agency PBL: Den Haag, The Netherlands; Institute for Environment and Sustainability IES, Joint Research Centre JRC: Ispra, Italy, 2013; p. 64, p Medium: ED.

7. Vlontzos, G.; Niavis, S.; Pardalos, P. Testing for environmental kuznets curve in the eu agricultural sector through an eco-(in) efficiency index. Energies 2017, 10, 1992. [CrossRef]

8. United Nations. World Population Prospects: The 2015 Revision; United Nations Secretariat: New York, NY, USA, 2015; p. 66.

9. Environment and Climate Change Canada. Global Greenhouse Gas Emissions. Available online: https://www.canada.ca/en/environment-climate-change/services/environmental-indicators/globalgreenhouse-gas-emissions.html (accessed on 5 May 2020).

10. Stern, D.I. The rise and fall of the environmental kuznets curve. World Dev. 2004, 32, 1419-1439. [CrossRef]

11. Kraft, J.; Kraft, A. On the relationship between energy and gnp. J. Energy Dev. 1978, 3, 401-403.

12. Kuznets, S. Economic growth and income inequality. Am. Econ. Rev. 1955, 45, 1-28.

13. Grossman, G.M.; Krueger, A.B. Environmental impacts of a north american free trade agreement. In Discussion Papers in Economics; Pinceton University: Princeton, NJ, USA, November 1991.

14. Stern, D.I. The environmental kuznets curve after 25 years. J. Bioecon. 2017, 19, 7-28. [CrossRef]

15. Kaika, D.; Zervas, E. The environmental kuznets curve (ekc) theory-Part a: Concept, causes and the $\mathrm{CO}_{2}$ emissions case. Energy Policy 2013, 62, 1392-1402. [CrossRef]

16. Kaika, D.; Zervas, E. The environmental kuznets curve (ekc) theory. Part b: Critical issues. Energy Policy 2013, 62, 1403-1411. [CrossRef]

17. Ozturk, I. A literature survey on energy-Growth nexus. Energy Policy 2010, 38, 340-349. [CrossRef]

18. Özokcu, S.; Özdemir, Ö. Economic growth, energy, and environmental kuznets curve. Renew. Sustain. Energy Rev. 2017, 72, 639-647. [CrossRef]

19. Dinda, S. Environmental kuznets curve hypothesis: A survey. Ecol. Econ. 2004, 49, 431-455. [CrossRef]

20. Bo, S. A literature survey on environmental kuznets curve. Energy Procedia 2011, 5, 1322-1325. [CrossRef]

21. Stern, D.I. The effect of nafta on energy and environmental efficiency in mexico. Policy Stud. J. 2007, 35, 291-322. [CrossRef] 
22. Sharif Hossain, $\mathrm{M}$. Panel estimation for $\mathrm{CO}_{2}$ emissions, energy consumption, economic growth, trade openness and urbanization of newly industrialized countries. Energy Policy 2011, 39, 6991-6999. [CrossRef]

23. Rahman, M.M.; Kashem, M.A. Carbon emissions, energy consumption and industrial growth in bangladesh: Empirical evidence from ardl cointegration and granger causality analysis. Energy Policy 2017, 110, 600-608. [CrossRef]

24. Kalayci, $\mathrm{C}$. The impact of economic globalization on $\mathrm{CO}_{2}$ emissions: The case of nafta countries. Int. J. Energy Econ. Policy 2019, 9, 356.

25. Roy Chowdhury, R.; Moran, E.F. Turning the curve: A critical review of kuznets approaches. Appl. Geogr. 2012, 32, 3-11. [CrossRef]

26. Sciubba, E.; Wall, G. A brief commented history of exergy from the beginnings to 2004. Int. J. Thermodyn. 2007, 10, 1-26.

27. Reistad, G.M. Available energy conversion and utilization in the united states. J. Eng. Power 1975, 97, 429-434. [CrossRef]

28. Dincer, I.; Rosen, M.A. Exergy: Energy, Environment and Sustainable Development, 2nd ed.; Elsevier Science: Amsterdam, The Netherlands, 2012.

29. BoroumandJazi, G.; Rismanchi, B.; Saidur, R. A review on exergy analysis of industrial sector. Renew. Sustain. Energy Rev. 2013, 27, 198-203. [CrossRef]

30. Arango-Miranda, R.; Hausler, R.; Romero-Lopez, R.; Glaus, M.; Ibarra-Zavaleta, S.P. Carbon dioxide emissions, energy consumption and economic growth: A comparative empirical study of selected developed and developing countries. "The role of exergy". Energies 2018, 11, 2668. [CrossRef]

31. Arango-Miranda, R.; Hausler, R.; Romero-López, R.; Glaus, M.; Ibarra-Zavaleta, S.P. An overview of energy and exergy analysis to the industrial sector, a contribution to sustainability. Sustainability 2018, 10, 153. [CrossRef]

32. Gong, M.; Wall, G. Exergy analysis of the supply of energy and material resources in the swedish society. Energies 2016, 9, 707. [CrossRef]

33. Utlu, Z.; Hepbasli, A. A review and assessment of the energy utilization efficiency in the turkish industrial sector using energy and exergy analysis method. Renew. Sustain. Energy Rev. 2007, 11, 1438-1459. [CrossRef]

34. Utlu, Z.; Hepbasli, A. Exergoeconomic aspects of sectoral energy utilization for turkish industrial sector and their impact on energy policies. Energy Policy 2009, 37, 577-587. [CrossRef]

35. International Energy Agency (I.E.A.). Energy Balances; International Energy Agency (IEA): Paris, France, 2017.

36. International Energy Agency (I.E.A.). World Energy Outlook 2017, OECD Publishing, Paris/IEA, Paris. Available online: http://doi.org/10.1787/weo-2017-en (accessed on 12 April 2020).

37. Website, E.U.O. The EU in Brief. Available online: https://europa.eu/european-union/about-eu/eu-in-brief_en (accessed on 28 April 2020).

38. Nejat, P.; Jomehzadeh, F.; Taheri, M.M.; Gohari, M.; Majid, M.Z.A. A global review of energy consumption, $\mathrm{CO}_{2}$ emissions and policy in the residential sector (with an overview of the top ten $\mathrm{CO}_{2}$ emitting countries). Renew. Sustain. Energy Rev. 2015, 43, 843-862. [CrossRef]

39. Burck, J.; Marten, F.; Bals, C.; Höhne, N. The Climate Change Performance Index: Results 2015; Germanwatch: Berlin, Germany, 2014; p. 32.

40. Sims, C.A. Money, income, and causality. Am. Econ. Rev. 1972, 62, 540-552.

41. Appiah, M.O. Investigating the multivariate granger causality between energy consumption, economic growth and $\mathrm{CO}_{2}$ emissions in ghana. Energy Policy 2018, 112, 198-208. [CrossRef]

42. Granger, C.W. Investigating causal relations by econometric models and cross-spectral methods. Econom. J. Econom. Soc. 1969, 37, 424-438. [CrossRef]

43. United Nations Development Programme (UNDP). Human Development Data (1990-2018). Available online: http://hdr.undp.org/en/data\# (accessed on 18 November 2019).

44. Grossman, G.M.; Krueger, A.B. Economic growth and the environment. Q. J. Econ. 1995, 110, 353-377. [CrossRef]

45. De Bruyn, S.M. Explaining the environmental kuznets curve: Structural change and international agreements in reducing sulphur emissions. Environ. Dev. Econ. 1997, 2, 485-503. [CrossRef]

46. Panayotou, T. Demystifying the environmental kuznets curve: Turning a black box into a policy tool. Environ. Dev. Econ. 1997, 2, 465-484. [CrossRef] 
47. Rehermann, F.; Pablo-Romero, M. Economic growth and transport energy consumption in the latin american and caribbean countries. Energy Policy 2018, 122, 518-527. [CrossRef]

48. Du, L.; Wei, C.; Cai, S. Economic development and carbon dioxide emissions in china: Provincial panel data analysis. China Econ. Rev. 2012, 23, 371-384. [CrossRef]

49. Magazzino, $\mathrm{C}$. A panel var approach of the relationship among economic growth, $\mathrm{CO}_{2}$ emissions, and energy use in the asean-6 countries. Int. J. Energy Econ. Policy 2014, 4, 546-553.

50. Khobai, H.; Le Roux, P. Does renewable energy consumption drive economic growth: Evidence from granger-causality technique. Int. J. Energy Econ. Policy 2018, 8, 205-212.

51. Toda, H.Y.; Yamamoto, T. Statistical inference in vector autoregressions with possibly integrated processes. J. Econom. 1995, 66, 225-250. [CrossRef]

52. Azam, A.; Rafiq, M.; Shafique, M.; Ateeq, M.; Yuan, J. Causality relationship between electricity supply and economic growth: Evidence from pakistan. Energies 2020, 13, 837. [CrossRef]

53. Ghali, K.H.; El-Sakka, M.I.T. Energy use and output growth in canada: A multivariate cointegration analysis. Energy Econ. 2004, 26, 225-238. [CrossRef]

54. He, J.; Richard, P. Environmental kuznets curve for $\mathrm{CO}_{2}$ in canada. Ecol. Econ. 2010, 69, 1083-1093. [CrossRef]

55. Olale, E.; Ochuodho, T.O.; Lantz, V.; El Armali, J. The environmental kuznets curve model for greenhouse gas emissions in canada. J. Clean. Prod. 2018, 184, 859-868. [CrossRef]

56. Gómez, M.; Ciarreta, A.; Zarraga, A. Linear and nonlinear causality between energy consumption and economic growth: The case of mexico 1965-2014. Energies 2018, 11, 784. [CrossRef]

57. Baek, J. Do nuclear and renewable energy improve the environment? Empirical evidence from the united states. Ecol. Indic. 2016, 66, 352-356. [CrossRef]

58. Dogan, E.; Turkekul, B. $\mathrm{CO}_{2}$ emissions, real output, energy consumption, trade, urbanization and financial development: Testing the ekc hypothesis for the USA. Environ. Sci. Pollut. Res. 2016, 23, 1203-1213. [CrossRef]

59. International Energy Agency (I.E.A.). Energy Policies Beyond IEA Countries: Mexico 2017; Agency, I.E.A., Ed.; IEA Publications: Paris, France, 2017; p. 211.

60. Soytas, U.; Sari, R.; Ewing, B.T. Energy consumption, income, and carbon emissions in the united states. Ecol. Econ. 2007, 62, 482-489. [CrossRef]

61. Falkner, R. The paris agreement and the new logic of international climate politics. Int. Aff. 2016, 92, 1107-1125. [CrossRef]

62. Angelou, N.; Elizondo Azuela, G.; Banerjee, S.G.; Bhatia, M.; Bushueva, I.; Inon, J.G.; Sarkar, A. Global tracking framework (No. 77889, pp. 1-289). The World Bank. 2013. Available online: https://www.worldbank.org/en/ topic/energy/publication/Global-Tracking-Framework-Report (accessed on 18 November 2019). 